\title{
CORRIGENDUM
}

\section{Truth, Pragmatism and Morality - CORRIGENDUM}

\section{DAVID WIGGINS}

doi:10.1017/S0031819113000375, Published by Cambridge University Press 21 May 2013.

In my recent article ${ }^{1}$ please replace note 4 , page 354 , with the following:

In An Inquiry into Meaning and Truth (London: George Allen \& Unwin Press, 1940), page 15, Bertrand Russell argued as follows 'Naïve realism leads to physics, and physics, if true, shows that naïve realism is false; therefore naïve realism, if true, is false; therefore it is false'. I note that Putnam's pragmatist, rather than temporize with Russell's mode of argument or his conclusion, will latch onto the second premiss and cast doubt upon Russell's claim that the comprehensive falsity of perceptual realism can be derived from the truth of physics.

\section{Reference}

${ }^{1}$ D. Wiggins. 'Truth, Pragmatism and Morality'. Philosophy 2013; 88, 351-368. 